\title{
Archaeology International
}

\section{Research Articles and Updates}

\section{Archaeology and legend: investigating Stonehenge}

Mike Parker Pearson ${ }^{1, *}$

How to cite: Parker Pearson, M. 'Archaeology and legend: investigating Stonehenge'. Archaeology International, 2021, 24 (1), pp. 144-64 • DOI: https://doi.org/10.14324/ 111.444.ai.2021.09

Published: 30 December 2021

\section{Peer review:}

This article has been peer-reviewed through the journal's standard double-blind peer review, where both the reviewers and authors are anonymised during review.

\section{Copyright:}

(C) 2021, Mike Parker Pearson. This is an open-access article distributed under the terms of the Creative Commons Attribution Licence (CC-BY) 4.0 https://creativecommons.org/licenses/by/4.0/, which permits unrestricted use, distribution and reproduction in any medium, provided the original author and source are credited • DOI: https://doi.org/10.14324/111.444.ai.2021.09

\section{Open access:}

Archaeology International is a peer-reviewed open-access journal. 


\title{
Archaeology and legend: investigating Stonehenge
}

Mike Parker Pearson

\begin{abstract}
Stonehenge is one of the world's most famous prehistoric monuments, built 4,500-5,000 years ago during the Neolithic in a time long before written history. The recent dramatic discovery of a dismantled stone circle near the sources of some of Stonehenge's stones in southwest Wales raises the fascinating possibility that an ancient story about Stonehenge's origin, written down 900 years ago and subsequently dismissed as pure invention, might contain a grain of truth. This article explores the pros and cons of comparing the legend with the archaeological evidence.
\end{abstract}

Keywords: Neolithic, Stonehenge, stone circles, Britain, legend

\section{Introduction}

Myths and legends have always inspired archaeologists and adventurers: Homer's Iliad in the search for Troy; the legend of King Arthur in the search for Camelot; or the Greek myth of Minos and the Minotaur's labyrinth in the discovery of Knossos. Often the myth proves elusive, as in the fruitless search for Eldorado's city of gold or the quest for Prester John's fabled lost kingdom. The complex relationship between archaeology and ancient legend is fraught with difficulties. What 
legends, if any, may be considered true? Might some contain only a kernel of truth, fortuitously resistant to the erosive sands of time? Or are they merely the vestiges of ever-changing stories from a bygone age that were intended only to entertain and moralise, and not to bear witness?

One of the earliest recorded tales of ancient Britain relates to the building of Stonehenge. Written by Geoffrey of Monmouth in about 1136, just six years or so after the very first documentary reference to Stonehenge by Henry of Huntingdon, it is a lengthy account of how Merlin the wizard organised, on behalf of Aurelius Ambrosius, the building of this great monument - supposedly a memorial for the fallen by taking megalithic stones from a previous stone circle in Ireland. This story is found in Historia Regum Britanniae (The History of the Kings of Britain, also known as De Gestis Britonum [On the Deeds of the Britons]), written by a cleric, Geoffrey of Monmouth (Galfridus Monemutensis). Although its title seemingly promised an accurate presentation of facts, it can best be described as a pseudo-history in which a few reliable historical facts are sprinkled among a morass of uncorroborated fictions and false claims (Wright 2007). Geoffrey's work may be better considered as a political statement to demonstrate the unity of Britain rather than an objective historical account (Flood 2016).

Although Geoffrey drew on a number of identifiable historical sources, including Gildas, Bede and supposedly 'a very old book in the British tongue', much of his writing is thought to have come from his own imagination. As early as 1190, William of Newburgh was claiming that most of Geoffrey's history relating to the time of Merlin and King Arthur was made up, partly by Geoffrey and partly by others (Chippindale 1994, 24). The passages that relate to Stonehenge (which he names as Stanheng; Wright 2007, 180) have no antecedent in any earlier writings, so the account's lack of historical pedigree places it in the category of 'fake' history unless proved otherwise. During the twentieth century scholars mused on whether any aspect of it might be true, with varying degrees of confidence in its possible veracity (Hibbard Loomis 1930; Piggott 1941). So why should we pay any attention to this story? What could it contain that might possibly relate to the purpose of Stonehenge? But, first, what does Geoffrey's story actually say about Stonehenge? 


\section{The legend of Merlin and Stonehenge}

According to Geoffrey, Stonehenge's origins lay in a time of conflict between Britons and invading Saxons in the aftermath of Roman rule. During a parlay at 'Ambrius' (Amesbury, close to the site of Stonehenge), 460 British aristocrats are treacherously murdered by King Hengist and his Saxons, carrying daggers under their clothes. Sometime later, the British king Aurelius Ambrosius replaces the previous king, Vortigern, unites the armies of Britain and defeats the Saxons. Wanting an everlasting memorial to the Britons killed at Mount Ambrius, he calls upon Merlin to devise a suitable monument. Merlin decrees that it should be built out of Chorea Gigantum (the Dance of the Giants/Giants' Dance/ Giants' Ring), a circle of enormous stones on the mountain of Killaraus in Ireland. 'If you set them up in the same pattern around the burial-place, they will stand forever' (Wright 2007, 172). According to Merlin, they had been erected by giants who used them for their magical and medicinal properties; whenever they fell sick, they set up baths among them, washed the stones and poured the water in the baths to be cured. It is these mystical stones that Merlin wants for his design of Stonehenge.

Merlin and the king's brother Uther Pendragon take 15,000 men to Ireland, defeat the Irish army and dismantle the stones, shipping them back to England and setting them up around the Britons' burial place at Mount Ambrius in the same manner as they had been in Ireland. As well as memorialising the British fallen, Stonehenge becomes the burial place first of Aurelius Ambrosius and then Uther Pendragon, father of King Arthur, the heroic war-leader of legend. The final royal burial at Stonehenge is Arthur's successor Constantinus, supposedly around $542 \mathrm{CE}$.

There are clearly major impediments to assuming that this story is in any way true. Stonehenge was built in the third millennium BCE and not in the 400s CE when Britons fought Saxons. Nor was there an ancient race of giants. And nor do Stonehenge's stones come from Ireland. Yet there are niggling questions that hint at possible grains of truth buried in this medieval legend. Among the remaining stones of Stonehenge are 43 'bluestones' which derive from the Preseli hills of southwest Wales, $275 \mathrm{~km}$ from Salisbury Plain (Figure 1). Might these somehow relate to the legend's account of a distant origin in Ireland? 


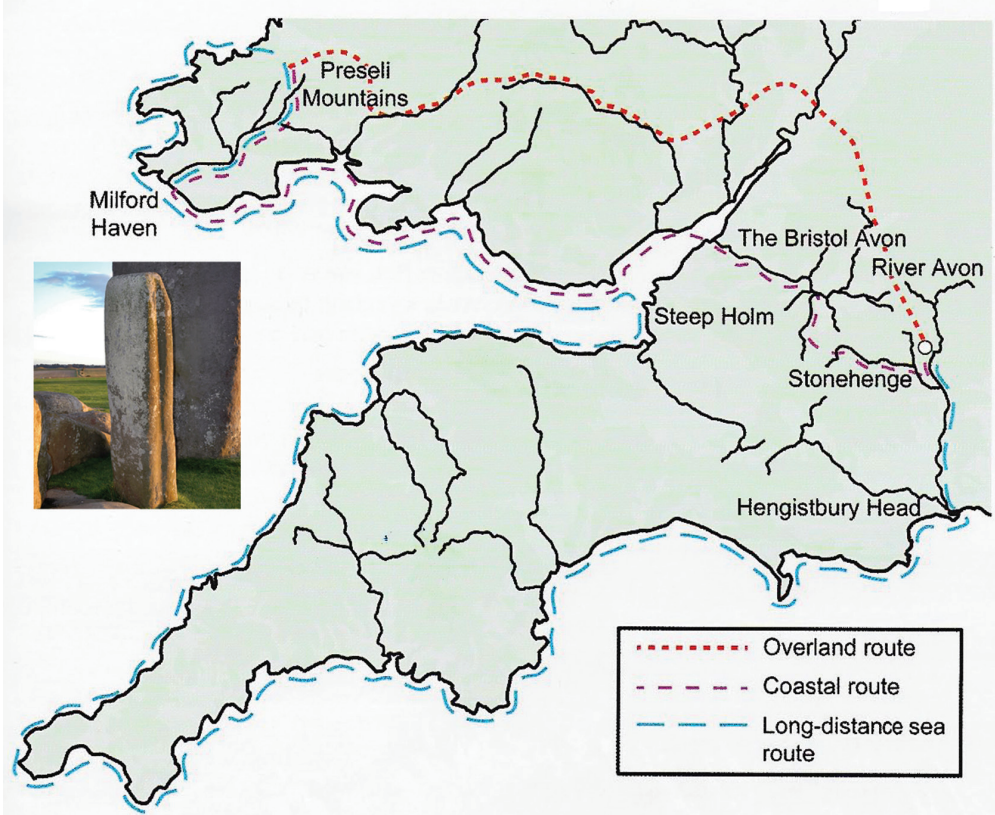

Figure 1 Stonehenge's bluestones (see inset) were brought from the Preseli hills, $275 \mathrm{~km}$ from Stonehenge. The sea and coastal routes now seem unlikely with the discovery that one of the stones (the Altar Stone) probably comes from an inland part of South Wales, along the postulated overland route (Source: Irene De Luis)

Of the hundreds of Britain's stone circles, only Stonehenge is composed of stones that have travelled a great distance. This fact could not have been known before the advent of the modern science of geology. Is it actually possible that knowledge of its distant sources was passed down by word of mouth over some 4,000 years from prehistory to Geoffrey's time? The question is even more pertinent when we consider that Pembrokeshire, the region of southwest Wales from which the bluestones derive, may well have been considered in the post-Roman and early medieval period to be part of Ireland. Irish kings were believed to have ruled this region in the centuries before Geoffrey's time, up to the end of the eleventh century (Davies 1982, 87-8, 95; 1990, 39), the area having been settled by the Irish 
probably from $400 \mathrm{CE}$ onwards (Davies 1982, 88). Yet this attribution is problematic; within a few pages of his story of the Dance of the Giants, Geoffrey talks of St David's in Pembrokeshire as being in Wales and not Ireland.

While Geoffrey's identification of Ireland as the source of Stonehenge's stones may be broadly compatible with the bluestones' origin in the Preseli hills of Pembrokeshire, there is no evidence for the existence anywhere of a Mount Killaraus (later referred to in William Caxton's Chronicle of England of 1480 as 'the mounte of kylyon'; Chippindale 1994, 25). So can the archaeological evidence help us further?

\section{Archaeological evidence}

Although antiquarians and archaeologists have studied Stonehenge for over 300 years, it is only recently that much attention has been paid to Geoffrey's story. In 2008 Timothy Darvill and Geoffrey Wainwright carried out an excavation at Stonehenge, developing their theory that Stonehenge had been built as a place of healing, drawing on one particular aspect of the tale (Darvill and Wainwright 2009, 16-18). They considered the bluestones to have arrived at Stonehenge around or after 2500 всE, linking their presence with nearby burials of people with unusual injuries (Darvill 2007). One of these was the Amesbury Archer, a Beaker migrant of 2480-2280 вCE from continental Europe with a damaged knee (Fitzpatrick 2011). Two others were Early Bronze Age people (c. 2000 вСЕ) whose skulls had been trepanned - suffering holes cut into their skulls - perhaps as a cure for illness.

The healing theory is not without problems. Excavations at Stonehenge in 2008 by a second team, the Stonehenge Riverside Project, produced evidence that the bluestones had been erected much earlier, during its first stage in 2995-2900 все (Parker Pearson et al. 2020, 168, 536), and that the monument had been used as a large cemetery from this time onwards for the next 300-600 years (Parker Pearson et al. 2009; 2020, 539-43; Willis et al. 2016). The burials with unusual injuries were most likely 600-1,000 years later than the arrival of the supposed 'healing' bluestones, which had in 
fact adorned a burial ground - a place of the dead rather than a place of healing. More appropriately, the motive of healing and curing fits well with the medieval ecclesiastical mindset. For example, just a few pages later in his History, Geoffrey twice refers to healing waters in contexts other than the Giants' Dance (Wright 2007, 115, 116). The claim that water splashed on stones of the Giants' Dance had healing properties is more likely to be an anachronistic fancy in the same way as the erroneous post-Roman date of Stonehenge.

Darvill and Wainwright had been searching since 2002 for the source of the bluestones in the Preseli hills of southwest Wales, the area identified by the geologist Herbert Thomas a century earlier (Thomas 1923). 'Bluestone' is a catch-all term for a variety of Stonehenge's monoliths, used to distinguish these small pillars from sarsens - the huge silcrete blocks that comprise the majority of Stonehenge's stones and most likely derive from West Woods, $24 \mathrm{~km}$ to the north (Parker Pearson 2016; Nash et al. 2020). Bluestones are actually a variety of rock types: spotted dolerite, unspotted dolerite, rhyolite, volcanics and sandstone. All derive from on and around the Preseli hills except for the sandstone Altar Stone, which comes from an as yet unidentified source (Ixer and Bevins 2011; Bevins et al. 2013, 2020; Ixer et al. 2017).

In 2011 geologists Richard Bevins and Rob Ixer published their identification of an impressive rocky outcrop at Craig Rhos-y-felin, just north of the Preseli hills, as a source of one of the types of rhyolite at Stonehenge (Figure 2). Two years later their geochemical analysis sourced spotted and unspotted dolerite stones from Stonehenge to two less spectacular outcrops in these hills, one at Carn Goedog and the other at Cerrigmarchogion (Bevins, Ixer and Pearce 2013). This was something of a bombshell because, ever since Thomas's time, archaeologists had been focused on a different location, the impressive outcrop of Carn Menyn or Carn Meini (see, for example, Atkinson 1956, 36-9); yet none of Stonehenge's bluestones in the new analysis matched the geology of this more prominent outcrop.

Armed with the geologists' dramatic discoveries, the Stonehenge Riverside team began investigations of the rhyolite and spotted dolerite sources at Craig Rhos-y-felin and Carn Goedog respectively. For the next five years, as part of the Stones of Stonehenge project, we carried 


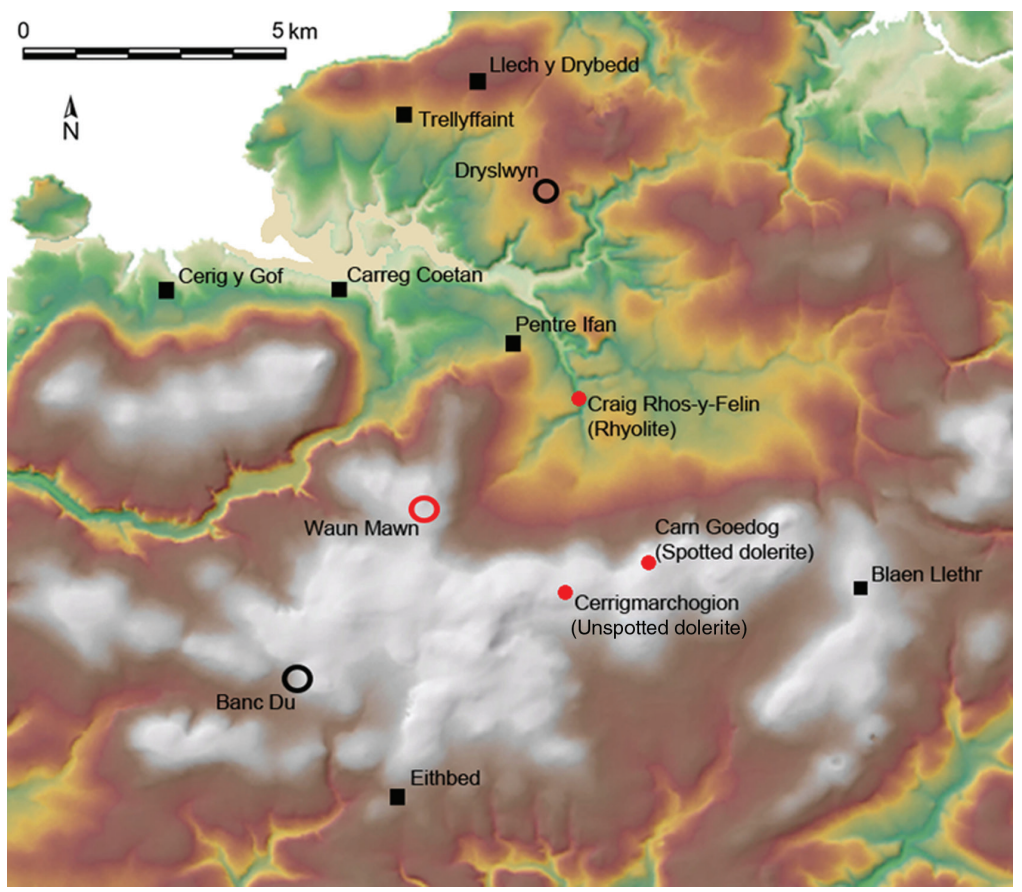

Figure 2 Location of the dismantled stone circle of Waun Mawn (red-ringed circle) as well as the bluestone sources of Carn Goedog (spotted dolerite), Craig Rhos-y-felin (rhyolite) and Cerrigmarchogion (unspotted dolerite). The locations of the Neolithic causewayed enclosure of Banc Du and palisaded enclosure of Dryslwyn (black-ringed circles), and Early Neolithic portal tombs (black squares) are also shown (Source: Mike Parker Pearson)

out excavations at the two outcrops. Both sites produced evidence of human activity, from the Mesolithic (8000-4000 BCE) to the medieval period, but especially from the Neolithic period in the centuries before and around 3000 BCE, just before the installation of bluestones at Stonehenge. This Neolithic evidence included stone tools and quarrying installations - gaps in the rock where pillars had been removed, artificial stone platforms onto which monoliths had been lowered and a trackway leading from the foot of one of the loading platforms (Parker Pearson et al. 2016; Parker Pearson, Bevins et al. 2015; Parker Pearson, Pollard et al. 2017, 2019). 
The aims of the Stones of Stonehenge project were to identify the bluestone quarries for Stonehenge and also to find out about the landscape context of these quarries. What was so special about the Preseli area in the Neolithic? It was already known that this region, including the valley of the River Nevern on the north side of the hills, was a focus for Early Neolithic settlement (4000-3400 BCE), judging by the concentration of dolmens and enclosures (Lynch 1972; Darvill and Wainwright 2016, 55-76). But what could be associated with the period of the bluestone quarries - the Middle Neolithic between 3400-3000 вСE? And why was there seemingly little trace of any activity in the Late Neolithic (3000-2500 вСЕ), the time of Stonehenge?

From 2012 onwards the Stones of Stonehenge project set out to explore the landscape around the bluestone quarries. With most of the agricultural land under permanent pasture, their survey methods included aerial photography, LiDAR (light detection and ranging), three-dimensional aerial photogrammetry and geophysics, coupled with excavation. Although numerous circular enclosures were identified as possible henges, all turned out to be sites of a much later date (Casswell, Comeau and Parker Pearson 2016; Parker Pearson, Caswell and Welham 2017; 2018). It seemed that the project had run out of road, and in 2017 the team members were ready to abandon the quest for Middle Neolithic sites. As a final move, we took a second look at a group of four standing stones on the hill of Waun Mawn, within $5 \mathrm{~km}$ of the bluestone quarries (Figure 3).

\section{Waun Mawn: a dismantled stone circle}

We had investigated the standing stones of Waun Mawn in 2011, carrying out geophysical surveys around the stones to see if their curving arrangement was due to their being remnants of a mostly demolished stone circle. This had been the interpretation of archaeologists a hundred years before (RCAHMW 1925, 258-9), although later archaeologists, including W.F. Grimes, a director of the Institute of Archaeology, had been sceptical of this interpretation (Grimes 1963, 150; Burl 1976, 371). Disappointingly, our magnetometer and resistivity surveys yielded no trace of buried stoneholes to indicate that the 


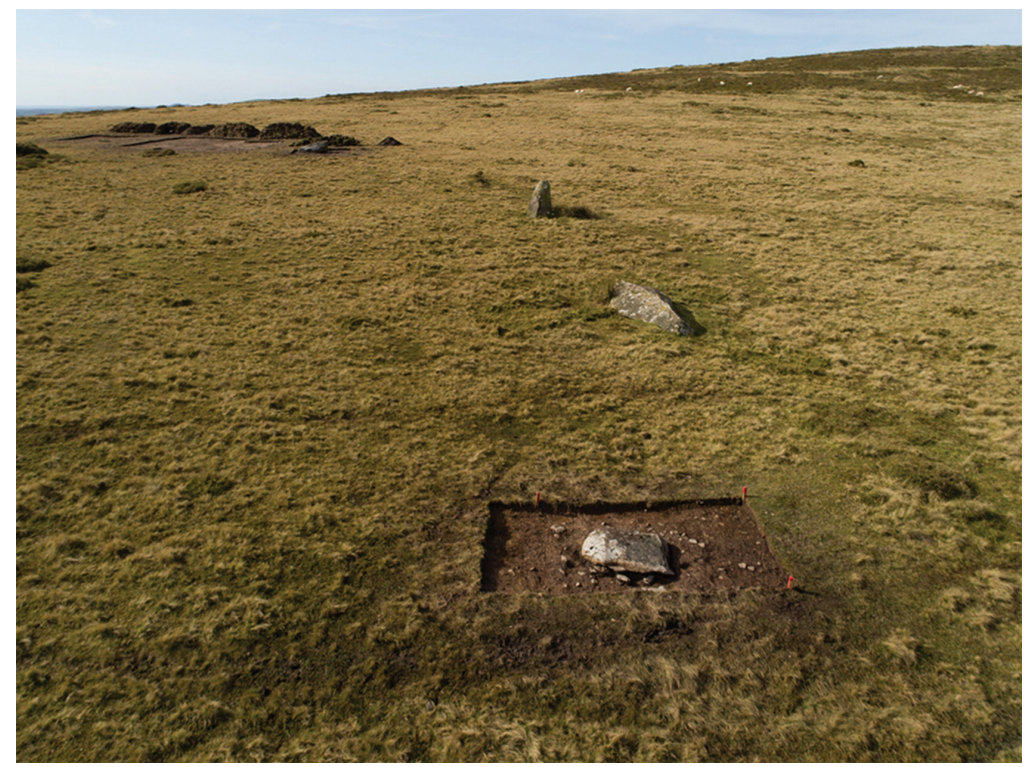

Figure 3 The arc of former standing stones at Waun Mawn during trial excavations in 2017, viewed from the east. Only one of them (third from the camera) is still standing. The stone in the foreground originally stood in a socket and formed one side of the solstice sunrise-oriented entrance of the former circle (Source: photograph by Adam Stanford)

arc of stones had originally formed part of a complete circle. It seemed that 'Peter' Grimes had been right to dismiss it.

With a last throw of the dice, we returned to Waun Mawn in 2017, this time with spades and shovels. Excavating beyond the ends of the arc, we uncovered two stoneholes that had once held standing stones, although the stones themselves were long gone. It was clear that the geophysical surveys in 2011 had not worked on the difficult terrain, so in 2018 we brought in teams of geophysicists who tried the full range of methods, including ground-penetrating radar and electromagnetic induction. With no positive results from any of the methods, even where we knew there were stoneholes, it was now clear that the poor magnetic and conductive properties of the underlying glacial drift were contributing to this problem. Geophysical survey was not going to help us, and the only way forward was to try to find more stoneholes by excavation. 
We returned to Waun Mawn in September 2021 with a team of staff, volunteers and students from UCL and the universities of Southampton and Bournemouth. In just three weeks of excavation by hand we discovered another four stoneholes, revealing that the surviving stones had indeed once been part of a stone circle $110 \mathrm{~m}$ in diameter, making it the third largest stone circle in Britain (Figure 4; Parker Pearson et al. 2021). The stoneholes were not particularly deep, but each bore at its base the imprint of the standing stone that had formerly stood in it. Most also had packing stones - small stone blocks jammed into the ground to stabilise the standing stone - even though the monoliths that originally stood in these holes had been removed.

Two of the stoneholes were different to the others. These were both on the northeast side of the circle and had no packing stones.

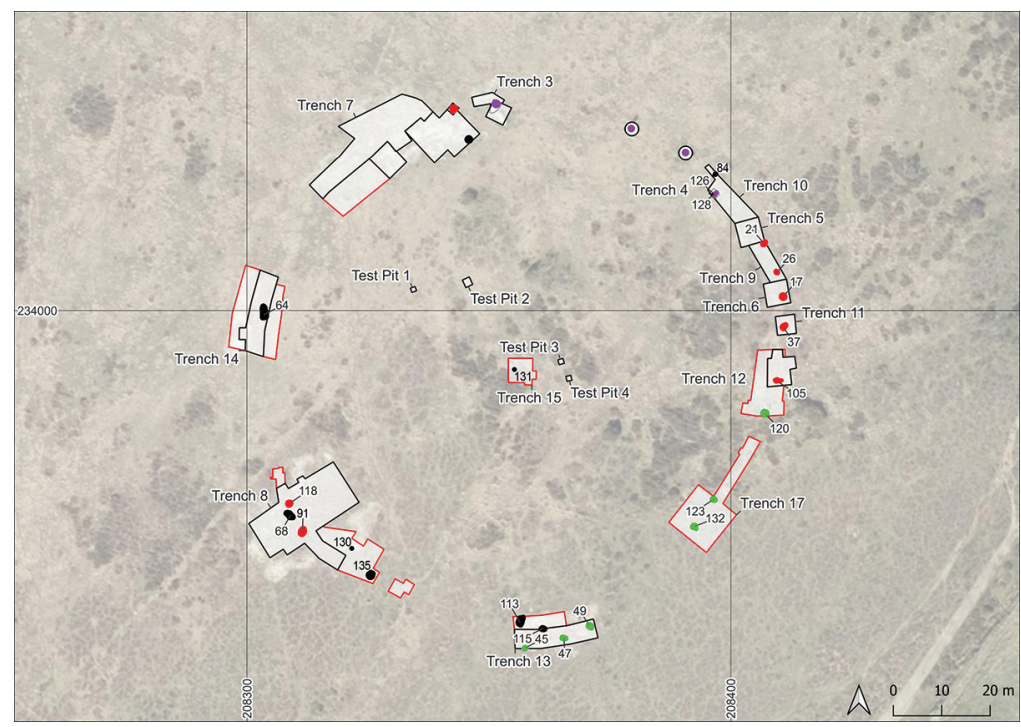

Figure 4 The excavation trenches (in black [2018] and red [2021]) at Waun Mawn, showing the locations of the four remaining standing stones (in purple), the additional stoneholes (in red), pits that never held stones (in green) and other features (in black). From the centre of the circle, the midsummer solstice sun rose within the entrance formed by Stoneholes 128 and 21 (Source: Chris Casswell and Kate Welham) 
Beside one of them was one of the four surviving standing stones, now lying on its side; it had obviously once stood in this hole. What was most unusual about these two stoneholes was the direction of their axis. Instead of having their long sides facing inwards to the centre of the circle, they were perpendicular to it. We realised that this 'gunsight' arrangement identified them as opposite sides of an entrance into the circle. Measurements taken by archaeoastronomer Clive Ruggles in 2019 revealed that the entrance faced towards the midsummer solstice sunset, similar to the famous orientation of Stonehenge (Figure 5).

A further surprise was our realisation that the diameter of Waun Mawn was the same as the diameter of the enclosing ditch around Stonehenge. As far as we know, no other Neolithic monument in Britain has this same diameter of $110 \mathrm{~m}$ (though several fall within the

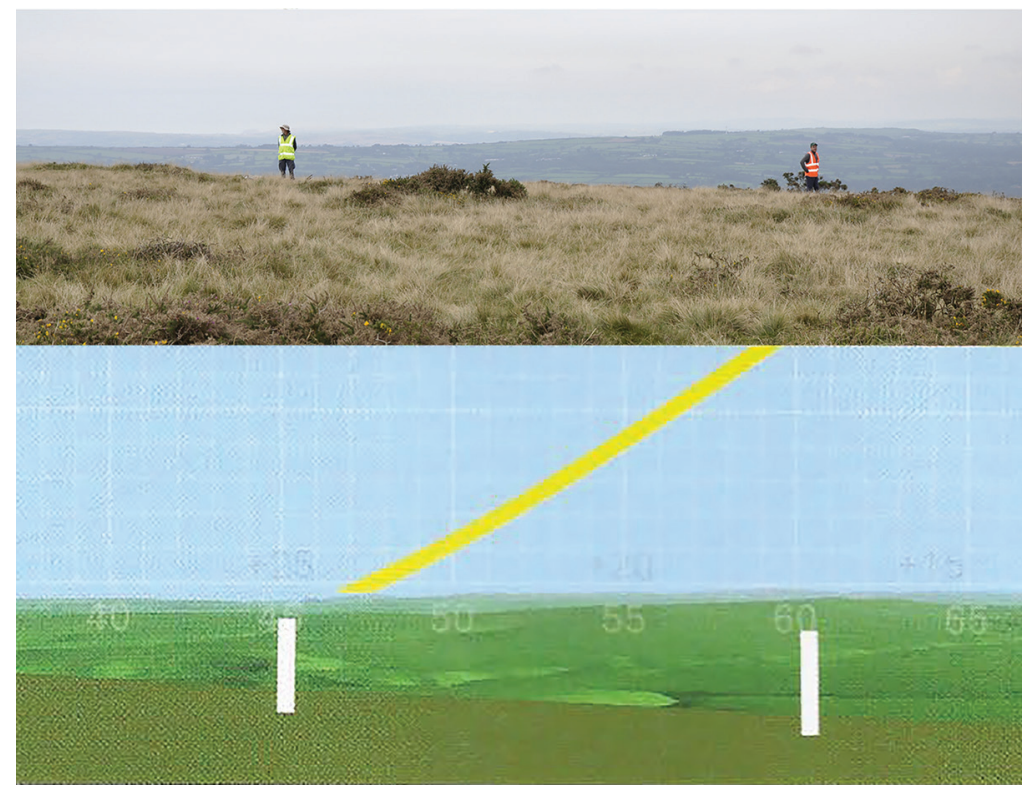

Figure 5 Positions of Waun Mawn's entrance stones as seen from the centre of the circle. The digitally generated profile shows the path of the rising summer solstice sun around 3300 всE (Source: Clive Ruggles) 
range of 13-100 m). This remarkable coincidence provides a further link between the two circles of Waun Mawn and Stonehenge. Yet the most important question to be answered about their relationship was whether the Waun Mawn circle dated to before Stonehenge (i.e. before 3000 вСЕ) and whether its vanished standing stones had been removed by the time that bluestones were set up at Stonehenge (also probably around or slightly after 3000 всE). Could Waun Mawn have been the original Stonehenge, the Dance of the Giants?

Dating these events of construction and dismantling at Waun Mawn would not be as easy as it might sound. While archaeologists working on prehistory mostly rely on radiocarbon dating, the acidic soils of southwest Wales destroy materials containing carbon, such as bones, wood or antler, except for charcoal. Although common on settlement sites, charcoal is exceedingly sparse on ceremonial sites such as stone circles. Through systematic flotation and fine sieving of the fills of the stoneholes, we recovered a few very small pieces of charred wood. These presented further problems because such small pieces are liable to be either residual (incorporated into the fill of a stonehole having been deposited in the soil centuries or millennia earlier) or intrusive (moved downwards into the stonehole by worm action centuries or millennia later). How could we tell which charcoal pieces dated to the time of the circle's construction and dismantling and which to before or after?

The way to answer these troubling questions was to employ a second method of dating alongside that of radiocarbon, which was carried out by Tim Kinnaird of the University of St Andrews. This method was optically stimulated luminescence (OSL) profiling and dating, a technique which measures the energy remnant in quartz-grained sediment since it was last exposed to light and estimates the time which has passed since that moment. It is less precise than radiocarbon dating, producing a wide error margin of 10 per cent, which covers the best part of a millennium when dating sediments laid down in the Neolithic. We realised, however, that it could provide broad parameters for the circle's dates of construction and dismantling.

Stone circles are difficult to date because of the general lack of suitable finds or dating materials. We are fortunate that Stonehenge is so well dated because of surviving antler tools and bones. Yet Britain's 
largest stone circle, Avebury, remains undated. Like Stonehenge, some of Britain's great stone circles date to the early third millennium BCE - Calanais in the Outer Hebrides (Ashmore 2016) and the Ring of Brodgar in Orkney (Richards 2013, 90-118). Also in Orkney, the Stones of Stenness are dated to 3020-2890 вСE (Schulting et al. 2010, 35-6). The small stone circle later covered by the passage tomb of Bryn Celli Ddu on Anglesey in the north of Wales is associated with cremation burials dating to 3500-3100 все and 3310-2900 все (Burrow 2010). Of closely comparable size to Waun Mawn, the circle of Long Meg and her Daughters in Cumbria, $172 \mathrm{~km}$ in diameter, is dated to 3340-3100 вСЕ on hazel charcoal from one of its stoneholes (Archaeological Services Durham University 2016). In summary, we can currently date the earliest stone circles to the Middle Neolithic - between 3400 всE and 3000 все - though they continued to be built throughout the Late Neolithic, with smaller circles constructed during the Copper Age and Bronze Age, continuing well after 2000 все (Bradley and Nimura 2016).

The OSL dates from packing deposits in Waun Mawn's stoneholes can be combined to produce a weighted probable date of construction of 3530 \pm 330 все (3860-3200 все). Sediments from the fills of the empty sockets provide a weighted probable date of dismantling before $2120 \pm 520$ вСе (2640-1600 вСЕ). This latter date, of course, may be much later than the actual date of dismantling since it is derived from sediments that filled the voids left by the removed stones. While this removal is likely to have taken place in the Neolithic, we cannot say just when.

Thirty-one radiocarbon dates on charcoal from Waun Mawn's stoneholes range from the Mesolithic to the Iron Age, although none fall within the Late Neolithic (3000-2500 вСE) or Copper Age (2500-2200 вСE). Only four coincide with the OSL dates for construction: 36703520 все, 3650-3520 вСе, 3500-3340 вСе and 3340-3030 вСе. The two dating methods together suggest that the Waun Mawn stone circle was constructed in 3400-3200 вСЕ. The date of 3340-3030 вСЕ is from charcoal within an emptied socket, so could provide a date for removal of the standing stone.

With further analysis ongoing to see if the dating of Waun Mawn can be refined, the current evidence reveals that Waun Mawn was left unfinished, abandoned in mid-construction, since holes were prepared 
for stones that they never held (see Figure 4). Of the standing stones that were put up, all but four were then dismantled, perhaps taken to Salisbury Plain to be erected in Stonehenge's first stage which began in 3080-2950 все (Parker Pearson et al. 2020, 164). There is a strong case that can be made for Stonehenge as a second-hand monument, constructed in its first stage out of bluestones that had graced Waun Mawn. Since the likely number of stones that once stood at Waun Mawn is unlikely to have numbered more than 15 , based on the positions of stoneholes, it is most likely that other bluestones either came direct from the quarries or derived from other, as yet undiscovered, stone circles in the Preseli area.

\section{The Dance of the Giants?}

There is the possibility that Waun Mawn could be the site of the Dance of the Giants. Its elevated location at $331 \mathrm{~m}$ OD on a high hill within the Preselis could qualify as a 'mountain'. The concordance of the stone circle's diameter, comparable to Stonehenge's Stage 1 enclosing ditch, echoes Geoffrey's words: 'erected ... round the cemetery exactly as they had stood on Mount Killaraus in Ireland'. Yet other features do not coincide. Waun Mawn shows no sign of any 'baths' for collecting water among the stones; perhaps this section of the narrative was entirely invented to provide some justification for the medieval mind of why the stones were so important that they had to be moved such an extraordinary distance. At the very best, the legend may preserve only the fact that there was a stone circle in the far west dismantled and moved to Stonehenge, and that Stonehenge was a memorial to the dead as demonstrated by its use as a cemetery.

More can be said about the motivation behind the bluestones' movement. The legend's account of the stones being forcibly taken is contradicted by recent evidence of mobility among those buried at Stonehenge. Strontium isotope analysis of cremated bone can establish movement between geological zones by an individual in the last decades of their lifetime (during the continuous process of bone remodelling). Analysis of 25 cremated individuals from Stonehenge has revealed that at least ten lived beyond the chalk of Salisbury Plain, four on geology consistent with that 
of southwest Wales (Snoeck et al. 2018). Interestingly, these four women and men are among the first people to have been buried at Stonehenge (since the latest of them dates to 3020-2900 вCE). Since Stonehenge's burials are likely to number 150 or more, these 4 out of 25 can be extrapolated to represent perhaps around 30 people of this external origin buried there. Since bone remodels within a decade or so to absorb the strontium isotope ratios of the underlying geology, any incomers who died more than a decade after moving would not show up by this method. Taking this possibility into account, perhaps as many as half of the people buried at Stonehenge could have been incomers; the 4 out of 25 thus potentially represent an initial migration, followed by their descendants living locally on and around the chalklands of the Stonehenge area.

This pattern of movement among the people of Stonehenge suggests that some came with the bluestones, that the stones were brought by the Neolithic inhabitants of Preseli and not taken by the invading force of a Neolithic Uther Pendragon. Just like the healing explanation, the story of seizure of the stones may also be erroneous. A new avenue of investigation is the possibility that the paucity of evidence for Late Neolithic activity in Preseli may represent a real pattern of out-migration around 3000 BCE.

Finally, one further aspect of the legend is of interest. The Neolithic people of Wales and western Britain can be differentiated from those of southeast England on the basis of both material culture (see, for example, Pioffet 2017) and genetic ancestry (Brace et al. 2019). This potential territorial separation between east and west, with Salisbury Plain in the borderland in between, echoes Geoffrey's anachronistic conflict between Saxons of the east and Britons of the west, meeting at a place of parlay. Given Stonehenge's location at a place that already had a tradition in the Neolithic of large-scale gatherings for feasting and monument building, its purpose may have been as a monument of unification (Childe 1957, 331; Gron et al. 2018; Parker Pearson 2012, 2019; Parker Pearson, Pollard et al. 2015; Parker Pearson et al. 2020). Its location between large-scale territorial groupings to the east and west may have enhanced its significance as a place of conflict resolution where groups from different regions could meet to resolve their differences. Perhaps Stonehenge really was erected in its first stage by 'Britons' (people in the west, as opposed to 
'Saxons' - people of the east) to commemorate a disastrous and bloody parlay gone wrong.

The antipathy of resident Britons and incoming Saxons can also be read as another anachronistic reworking of a second prehistoric encounter, this time around 2500 всE, when the second stage of Stonehenge involved the erection of the great sarsens as a horseshoe of five trilithons surrounded by a circle of lintelled sarsens. This major rebuilding of Stonehenge, when it took the form that it largely has today, took place on the eve of the arrival of new practices from the Continent. Recent genetic analysis of ancient DNA has revealed that the people introducing new rites of inhumation burial accompanied by a pot and other grave goods - the so-called Beaker people - have genetic ancestries distinct from the Neolithic population of Britain (Olalde et al. 2018). Although the earliest Beaker burials date to 2450-2325 все (Jay et al. 2019, 75), it is very possible that the first Beaker people arrived in Britain in earlier decades in a 'contact' scenario that has left few archaeological traces. It is just possible that the legend preserves a folk memory of this event, the outcome of which was to be as transformative of prehistoric society as the Saxons' invasion was for early medieval England.

\section{Conclusion: the longevity of oral tradition}

The various concordances between legend and reality at Stonehenge might be entirely dismissed as no more than coincidence if we can be certain that oral traditions have little or no chance of lasting 4,000 years. An acceptable limit would seem to be 500 years in many cases (Parker Pearson 2012, 280). Homer's Iliad is thought to have been composed around 700 всE, drawing on oral history of events that took place 500 years earlier. In traditional societies today, such as in southern Madagascar and Highland New Guinea, it is possible that some oral traditions also go back as far as 500 years (Parker Pearson et al. 1999; Weissner and Tumu 1998). On the Pacific island of Vanuatu, the memory of Chief Roy Mata has persisted for nearly 800 years (Garanger 1972). An even older oral history of coastal abandonment by the Tsimshian of the Pacific Northwest region of 
British Columbia has been corroborated by simulation-based modelling of radiocarbon dating, placing this event $1,200-1,100$ years ago (Edinborough et al. 2017).

Greater claims are made for India's oldest Sanskrit texts, the Vedas. These are reckoned to have originated in the Late Bronze Age, around 1000 вСE, and to have been transmitted orally over a period of some 3,000 years (Gerety 2017). There are even claims for oral history dating back 10,000 years or more, relating to sea-level changes on the northwest coast of North America (McLaren et al. 2015, 161-2). Australian Aboriginal oral tradition relating to ancient flood events has been claimed as evidence of transmitted memory of early Holocene sea-level rise some 7,000 years ago (Nunn 2018).

In a worldwide survey of deep-time oral traditions, David Henige (2009) points out many of the problems of trying to tie oral history to ancient geological events that occurred many thousands of years ago. The two cases of sea-level rise just mentioned are examples of the many flood myths found in different cultures throughout the world and which need not have any basis in reality. According to Henige, such claims for deep-time transmission of oral histories are, in the words of his article's title, 'impossible to disprove but impossible to believe'.

Scholars ... can assume that indeed oral traditions can be, and often are, transmitted intact as many as hundreds of times, immune to internal and external influences all along the way. Or they can assume instead that during the course of these transmissions many influences affected and changed the content of these traditions, ending with the incorporation of outside matter ... Given these two mutually exclusive choices, it seems impossible to choose the first. (Henige 2009, 226)

We should further consider that the British situation is likely to have differed from these cases drawn from Australia, Vanuatu, the preColombian Americas and elsewhere. While these can be characterised as Indigenous cultures with long-term continuities of tradition, there is evidence for substantial cultural and population discontinuity across the last four millennia of Britain's prehistory and early history, starting with the arrival of the Beaker people in the mid-third millennium BCE 
(Olalde et al. 2018; Parker Pearson, Sheridan et al. 2019). We have to conclude that, in the case of Stonehenge, an oral tradition surviving from around 3000-2500 BCE until the twelfth century CE is most probably beyond the limits of survivable transmission.

Archaeology's long-term relationship with folkloric studies has diverged in the last few decades, despite the need for collaboration between disciplines (Paphitis 2013). For the time being, at least, we have to keep the legend separate from the archaeological evidence, even though, as the archaeologist Stuart Piggott observed long ago, they have intriguing points of correspondence which may just be too remarkable to be dismissed as mere coincidence (Piggott 1941, 306). On the one hand, Geoffrey's tale cannot be used to 'flesh out' the bones of the archaeological story. Yet on the other - just maybe - aspects of the legend might help us peer into the vanished world of prehistory.

\section{Acknowledgements}

Thanks are due to the Barony of Cemaes, Cyfoeth Naturiol Cymru (Natural Resources Wales) and the Pembrokeshire Coast National Park for permissions to excavate at Waun Mawn. The excavations and research in 2017, 2018 and 2021 were funded by the Gerda Henkel Stiftung (grant Nos: AZ 11/V/17, AZ 08/V/18 \& AZ 66/V/19), the Rust Family Foundation, the NERC Radiocarbon Panel and Raw-Cut TV. The field project was co-directed with Josh Pollard, Colin Richards and Kate Welham, with help from Richard Bevins (geology), Chris Casswell (excavation), Kevan Edinborough (radiocarbon dating), Rob Ixer (geology), Tim Kinnaird (OSL dating), Clive Ruggles (astronomy), Jim Rylatt (excavation), Dave Shaw (excavation), Ellen Simmons (charred wood analysis) and Adam Stanford (aerial photography). Finally, I thank the two anonymous reviewers for their insightful comments which have helped substantially to improve the initial draft.

\section{Conflict of interests}

The author declares no conflicts of interest with this work. 


\section{References}

Archaeological Services Durham University. 2016. 'Long Meg and her daughters, Little Salkeld, Cumbria: post-excavation full analysis', https://altogetherarchaeology. org/ReportsandProposalDocs/LongMeg/ LongMegFA4043.pdf.

Ashmore, P. 2016. Calanais: Survey and excavation, 1979-88. Edinburgh: Historic Environment Scotland. https:// www.historicenvironment.scot/ archives-and-research/publications/ publication/?publicationId $=$ b6aee 5fd-5980-4872-a2e0-a63c00cc7b68.

Atkinson, R.J.C. 1956. Stonehenge. London: Hamish Hamilton.

Bevins, R.E., R.A. Ixer and N. Pearce. 2013. 'Carn Goedog is the likely major source of Stonehenge doleritic bluestones: Evidence based on compatible element geochemistry and principal components analysis', Journal of Archaeological Science 42: 179-93.

Bevins, R.E., D. Pirrie, R.A. Ixer, H. O’Brien, M. Parker Pearson, M. Power and R. Shail. 2020. 'Constraining the provenance of the Stonehenge "Altar Stone": Evidence from automated mineralogy and $\mathrm{U}-\mathrm{Pb}$ zircon age dating', Journal of Archaeological Science 120. https://doi.org/10.1016/j. jas.2020.105188.

Brace, S., Y. Diekmann, T.J. Booth, Z. Faltyskova, N. Rohland, S. Mallick, M. Ferry, M., Michel, J. Oppenheimer, N. Broomandkhoshbacht et al. 2019. 'Ancient genomes indicate population replacement in Early Neolithic Britain', Nature: Ecology and Evolution 3(5): 765-71.

Bradley, R.J., and C. Nimura, eds. 2016. The Use and Reuse of Stone Circles: Fieldwork at five Scottish monuments and its implications. Oxford: Oxbow.

Burl, A. 1976. The Stone Circles of the British Isles. New Haven: Yale University Press.

Burrow, S. 2010. 'Bryn Celli Ddu passage tomb, Anglesey: Alignment, construction, date and ritual', Proceedings of the Prehistoric Society 76: 249-70.
Casswell, C., R. Comeau and M. Parker Pearson. 2016. 'An early medieval cemetery and circular enclosure at Felindre Farchog, north Pembrokeshire', Archaeology in Wales 56: 100-6.

Childe, V.G. 1957. The Dawn of European Civilization. 6th edition. London: Routledge \& Kegan Paul.

Chippindale, C. 1994. Stonehenge Complete. 2nd edition. London: Thames \& Hudson.

Darvill, T.C. 2007. 'Towards the within: Stonehenge and its purpose'. In Cult in Context: Reconsidering Ritual in Archaeology, edited by D.A. Barraclough and C. Malone, 148-57. Oxford: Oxbow.

Darvill, T.C., and G.J. Wainwright. 2009. 'Stonehenge excavations 2008', Antiquaries Journal 89: 1-19.

Darvill, T.C., and G.J. Wainwright. 2016. 'Neolithic and Bronze Age Pembrokeshire'. In Prehistoric, Roman and Early Medieval Pembrokeshire. Pembrokeshire County History, Volume I, 55-222. Haverfordwest: Pembrokeshire County History Trust.

Davies, W. 1982. Wales in the Early Middle Ages. Leicester: Leicester University Press.

Davies, W. 1990. Patterns of Power in Early Wales. Oxford: Clarendon Press.

Edinborough, K., M. Porčić, A. Martindale, T.J. Brown, K. Supernant and K.M. Ames. 2017. 'Radiocarbon tests for demographic events in written and oral history', Proceedings of the National Academy of Sciences 114: 12436-41.

Fitzpatrick, A.P. 2011. The Amesbury Archer and the Boscombe Bowmen: Bell Beaker burials at Boscombe Down, Amesbury, Wiltshire. Oxford: Oxbow.

Flood, N. 2016. Prophecy, Politics and Place in Medieval England: From Geoffrey of Monmouth to Thomas of Erceldoune. Woodbridge: D.S. Brewer.

Garanger, J. 1972. Archéologie des NouvellesHébrides: Contribution à la connaissance des îles du Centre. Paris: ORSTOM.

Grimes, W.F. 1963. 'The stone circles and related monuments of Wales'. In Culture and Environment: Essays in honour of Sir Cyril Fox, edited by I. Foster and 
L. Alcock, 93-152. London: Routledge \& Kegan Paul.

Gron, K.J., P. Rowley-Conwy, E. FernandezDominguez, D.R. Gröcke, J. Montgomery, G.M. Nowell and W.P. Patterson. 2018. 'A meeting in the forest: Hunters and farmers at the Coneybury "anomaly", Wiltshire', Proceedings of the Prehistoric Society 84: 111-44.

Gerety, F.M.M. 2017. 'Vedic oral tradition'. In Oxford Bibliographies on Hinduism, edited by T. Coleman. New York: Oxford University Press. https://doi.org/10.1093/ OBO/9780195399318-0184.

Henige, D. 2009. 'Impossible to disprove but impossible to believe: The unforgiving epistemology of deep-time oral tradition', History in Africa 36: 127-234.

Hibbard Loomis, L. 1930. 'Geoffrey of Monmouth and Stonehenge', PMLA 45: 400-15.

Ixer, R.A., and R.E. Bevins. 2011. 'Craig Rhos-y-felin, Pont Saeson is the dominant source of the Stonehenge rhyolitic "debitage"', Archaeology in Wales 50: 21-32.

Ixer, R.A., P. Turner, S. Molyneux and R.E. Bevins. 2017. 'The petrography, geological age and distribution of the Lower Palaeozoic Sandstone debitage from the Stonehenge landscape', Wiltshire Archaeological and Natural History Magazine 110: 1-16.

Jay, M., M.P. Richards and P. Marshall. 2019. 'Radiocarbon dates and their Bayesian modelling'. In The Beaker People: Isotopes, mobility and diet in prehistoric Britain, edited by M. Parker Pearson, A. Sheridan, M. Jay, A. Chamberlain, M.P. Richards and J. Evans, 42-80. Oxford: Oxbow.

Lynch, F.M. 1972. 'Portal dolmens in the Nevern valley, Pembrokeshire'. In Prehistoric Man in Wales and the West, edited by F.M. Lynch and C. Burgess, 67-84. Bath: Adams \& Dart.

McLaren, D., F. Rahemtulla, E. Gitla (White) and D. Fedje. 2015. 'Prerogatives, sea level, and the strength of persistent places: Archaeological evidence for long-term occupation of the central coast of British Columbia', BC Studies 187: 155-91.
Nash, D., T.J.R. Ciborowski, J.S. Ullyot, M. Parker Pearson, T. Darvill, S. Greaney, G. Maniatis and K.A. Whitaker. 2020. 'Origins of the sarsen megaliths at Stonehenge', Science Advances 6. https:// doi.org/10.1126/sciadv.abc0133.

Nunn, P. 2018. The Edge of Memory: Ancient stories, oral tradition and the post-glacial world. London: Bloomsbury.

Olalde, I., S. Brace, M. Allentoft, I. Armit, K. Kristiansen, N. Rohland, S. Mallick, T. Booth, A. Szécsényi-Nagy, E. Altena et al. 2018. 'The Beaker phenomenon and the genomic transformation of northwest Europe', Nature 555 (7695): 190-6.

Paphitis, T. 2013. '"Have you come to take the king away?": A survey of archaeology and folklore in context', Papers from the Institute of Archaeology 23: Article 16. http://doi.org/10.5334/pia.434.

Parker Pearson, M. 2012. Stonehenge: Exploring the greatest Stone Age mystery. London: Simon \& Schuster.

Parker Pearson, M. 2016. 'The sarsen stones of Stonehenge', Proceedings of the Geologists'Association 127: 363-9.

Parker Pearson, M. 2019. 'Stonehenge's bluestones'. In Mining and Quarrying in Neolithic Europe: A social perspective, edited by A. Teather, P. Topping and J. Baczkowski, 83-100. Oxford: Oxbow.

Parker Pearson, M., R.E. Bevins, R.A. Ixer, J. Pollard, C. Richards, K. Welham, B. Chan, K. Edinborough, D. Hamilton, R. Macphail et al. 2015. 'Craig Rhos-y-felin: A Welsh bluestone megalith quarry for Stonehenge', Antiquity 89: 1331-52.

Parker Pearson, M., C. Casswell and K. Welham. 2017. 'Excavations at Castell Mawr Iron Age hillfort, Pembrokeshire', Archaeologia Cambrensis 166: 141-73.

Parker Pearson, M., C. Casswell and K. Welham. 2018. 'A Late Bronze Age ringfort at Bayvil Farm, north Pembrokeshire', Archaeologia Cambrensis 167: 113-41.

Parker Pearson, M., A. Chamberlain, M. Jay, P. Marshall, J. Pollard, C. Richards, J. Thomas, C. Tilley and K. Welham. 2009. 'Who was buried at Stonehenge?', Antiquity 83: 23-39.

Parker Pearson, M., K. Godden, R. Ramilisonina, J.-L. Schwenninger and H. Smith. 1999. 'Lost kingdoms: 
Oral histories, travellers' tales and archaeology in southern Madagascar'. In Historical Archaeology: Back from the edge, edited by P. Funari, M. Hall and S. Jones, 233-54. London: Routledge.

Parker Pearson, M., J. Pollard, C. Richards, D. Schlee and K. Welham. 2016. 'In search of the Stonehenge quarries', British Archaeology 146: 16-23.

Parker Pearson, M., J. Pollard, C. Richards, J. Thomas, C. Tilley and K. Welham, eds. 2020. Stonehenge for the Ancestors. Part 1: Landscape and monuments. Leiden: Sidestone Press.

Parker Pearson, M. with J. Pollard, C. Richards, J. Thomas and K. Welham. 2015. Stonehenge: Making sense of a prehistoric mystery. York: CBA.

Parker Pearson, M., J. Pollard, C. Richards and K. Welham. 2017. 'The origins of Stonehenge: On the track of the bluestones', Archaeology International 20: 54-9.

Parker Pearson, M., J. Pollard, C. Richards, K. Welham, C. Casswell, D. Shaw, E. Simmons, A. Stanford, R.E. Bevins and R.A. Ixer. 2019. 'Megalithic quarries for Stonehenge's bluestones', Antiquity 93, 45-62.

Parker Pearson, M., J. Pollard, C. Richards, K. Welham, T. Kinnaird, D. Shaw, E. Simmons, A. Stanford, R.E. Bevins, R.A. Ixer et al. 2021. 'The original Stonehenge? A dismantled stone circle in the Preseli hills of west Wales', Antiquity 95.

Parker Pearson, M., A. Sheridan, M. Jay, A. Chamberlain, M.P. Richards and J. Evans, eds. 2019. The Beaker People: Isotopes, mobility and diet in prehistoric Britain. Oxford: Oxbow.

Piggott, S. 1941. 'The sources of Geoffrey of Monmouth: II. The Stonehenge story', Antiquity 15: 305-19.
Pioffet, H. 2017. 'Societies and identities during the Early Neolithic of Britain and Ireland in their west European context: Characterisation and comparative analyses of pottery production between Channel, Irish Sea and North Sea', Past 87, 5-7.

RCAHMW. 1925. An Inventory of the Ancient Monuments in Wales and Monmouthshire. Volume VII, County of Pembroke. London: HMSO.

Richards, C., ed. 2013. Building the Great Stone Circles of the North. Oxford: Windgather.

Schulting, R.J., J.A. Sheridan, R. Crozier and E. Murphy. 2010. 'Revisiting Quanterness: New AMS dates and stable isotope data from an Orcadian chamber tomb', Proceedings of the Society of Antiquaries of Scotland 140: 1-50.

Snoeck, C.J., J. Pouncett, P. Claeys, S. Goderis, N. Mattielli, M. Parker Pearson, C. Willis, A. Zazzo, J. Lee-Thorp and R. Schulting. 2018. 'Strontium isotope analysis on cremated human remains from Stonehenge support links with west Wales', Scientific Reports 8 (10790).

Thomas, H.H. 1923. 'The source of the stones of Stonehenge', Antiquaries Journal 3: 239-60.

Weissner, P. and A. Tumu. 1998. Historical Vines: Enga networks of exchange, ritual, and warfare in Papua New Guinea. Bathurst: Crawford House.

Willis, C., P. Marshall, J.I. McKinley, M. Pitts, J. Pollard, C. Richards, J. Richards, J. Thomas, T. Waldron, K. Welham and M. Parker Pearson. 2016. 'The dead of Stonehenge', Antiquity 90: 337-56.

Wright, N. 2007. Geoffrey of Monmouth: The history of the kings of Britain (ed. Michael D. Reeve). An edition and translation of De gestis Britonum [Historia regum Britanniae]. (Arthurian Studies 69). Woodbridge: Boydell and Brewer. 